\title{
Acute HIV infection syndrome mimicking COVID-19 vaccination side effects: a case report
}

\author{
Julian Triebelhorn ${ }^{1 *}$, Stefanie Haschka ${ }^{1}$, Felix Hesse ${ }^{1}$, Johanna Erber ${ }^{1}$, Simon Weidlich' ${ }^{1}$, Marcel Lee ${ }^{1}$, \\ Dieter Hoffmann², Josef Eberle ${ }^{3}$ and Christoph D. Spinner ${ }^{1}$
}

\begin{abstract}
Background: Symptoms of primary HIV infection, including fever, rash, and headache, are nonspecific and are often described as flu-like. COVID-19 vaccination side effects, such as fever, which occur in up to 10\% of people following COVID-19 vaccination, can make the diagnosis of acute HIV infection even more challenging.

Case presentation: A 26-year-old man presented with fever and headache following COVID-19 vaccination. The symptoms were initially thought to be vaccine side effects. A diagnostic workup was conducted due to persisting fever and headache $>72 \mathrm{~h}$ following vaccination, and he was diagnosed with Fiebig stage II acute HIV infection, 3 weeks after having unprotected anal intercourse with another man.
\end{abstract}

Conclusion: Thorough anamnesis is key to estimating the individual risk of primary HIV infection, in patients presenting with flu-like symptoms. Early diagnosis and initiation of antiretroviral therapy is associated with better prognosis and limits transmission of the disease.

Keywords: Acute HIV infection, COVID-19, Vaccination, HIV seroconversion illness, Fiebig, Seroconversion

\section{Background}

HIV seroconversion describes the initial immune response of developing human immunodeficiency virus (HIV)-specific antibodies, which typically become detectable 22-24 days after infection (Table 1). Fiebig et al. [1] subdivided the process of HIV seroconversion into six stages, depending on the antibody-antigen pattern and HIV viral load in the blood. This classification allows a precise description of patients with primary HIV infection. In $89 \%$ of cases, the process of seroconversion is accompanied by symptoms, known as HIV seroconversion illness [2]. Symptoms often include malaise, headache, fever, generalized lymphadenopathy, diarrhea, and rash. In severe cases patients may experience

\footnotetext{
${ }^{*}$ Correspondence: julian.triebelhorn@mri.tum.de

${ }^{1}$ Department of Internal Medicine II, University Hospital Rechts Der Isar,

School of Medicine, Technical University of Munich, Ismaninger-Straße 22, 93675 Munich, Germany

Full list of author information is available at the end of the article
}

meningeal symptoms that require hospitalization. The common symptoms of HIV seroconversion are nonspecific and are often described as flu-like, making it difficult to distinguish between HIV seroconversion illness and a wide range of other conditions, including vaccine side effects. During the COVID-19 mass vaccination period within the ongoing COVID-19 pandemic, vaccine side effects should be considered in the differential diagnosis, provided that the patient had recently been vaccinated. COVID-19 vaccine side effects include fatigue, redness, fever, arthralgia, and headache, and may resemble symptoms of HIV seroconversion illness, thus impeding the diagnosis of HIV [3].

We describe a case of HIV seroconversion illness that was initially misdiagnosed as a COVID-19 vaccine side effect, to illustrate the similarities between common COVID-19 vaccination side effects and the diagnostic process needed to differentiate the two conditions. original author(s) and the source, provide a link to the Creative Commons licence, and indicate if changes were made. The images or other third party material in this article are included in the article's Creative Commons licence, unless indicated otherwise in a credit line to the material. If material is not included in the article's Creative Commons licence and your intended use is not permitted by statutory regulation or exceeds the permitted use, you will need to obtain permission directly from the copyright holder. To view a copy of this licence, visit http://creativecommons.org/licenses/by/4.0/. The Creative Commons Public Domain Dedication waiver (http://creativecommons.org/publicdomain/zero/1.0/) applies to the data made available in this article, unless otherwise stated in a credit line to the data. 
Table 1 Stages of HIV markers/ diagnostic tests in early infection, as described by Fiebig et al.

\begin{tabular}{|c|c|c|c|c|c|c|}
\hline Fiebig stage & HIV-PCR & $\begin{array}{l}\text { 4th-generation } \\
\text { screening test }\end{array}$ & Western blot & p24- antigen & Antibodies & Days since infection \\
\hline Eclipse & - & - & - & - & - & $0-11$ \\
\hline । & + & - & - & - & - & $12-16$ \\
\hline$\|$ & + & + & - & + & - & $17-21$ \\
\hline III & + & + & - & + & HIV-IgM: + & $22-24$ \\
\hline IV & + & + & inconclusive & $+1-$ & $2 / 3$ antibodies positive $(\mathrm{p} 24, \mathrm{gp} 41, \mathrm{gp} 120)$ & $25-30$ \\
\hline V & + & + & + & $+1-$ & $\begin{array}{l}3 / 3 \text { antibodies positive (p24, gp } 41, \text { gp120) lacking } \\
\text { p31 }\end{array}$ & $31-100$ \\
\hline $\mathrm{VI}$ & + & + & + & $+/-$ & $\begin{array}{l}\text { 3/3 antibodies positive (p24, gp } 41, \mathrm{gp} 120) \\
\text { p31-antibodies positive }\end{array}$ & Open-ended \\
\hline
\end{tabular}

The table is as described by Fiebig et al., modified after $[1,4,5]$. Results of diagnostic tests (HIV-PCR, fourth-generation screening tests, Western blot) and detectability of HIV markers (p24-antigen, HIV-specific antibodies) are shown in relation to days since infection. (+) indicates positive test result/ detectability, (-) indicates negative test result/ HIV-marker not detectable. Eclipse and Fiebig stages are listed in dependence of HIV-marker, as described by Fiebig et al.

\section{Case report}

One day after receiving the first dose of COVID-19 vaccine with mRNA-1273 (Moderna Biotech, Cambridge, Massachusetts, USA) a 26-year-old German man developed fever, shivering and headache. During the following days, he developed rash, vertigo and nausea, culminating in a single syncopal episode 8 days after the vaccination, as shown in Fig. 1. The patient was referred to the nearest local hospital because his symptoms were suspected to be due to vaccine-associated side effects. He was provided with analgesics and fluid, and the symptoms rapidly resolved. Detailed sexual history-taking revealed an episode of unprotected anal intercourse with another man 23 days previously. He subsequently tested positive for HIV on a fourth-generation p24/ab-enzyme-linked immunosorbent assay (ELISA). The patient was referred to our tertiary medical center for further assessment and initiation of treatment.

On arrival, the patient complained of a mild headache, general weakness and persisting skin flushing.

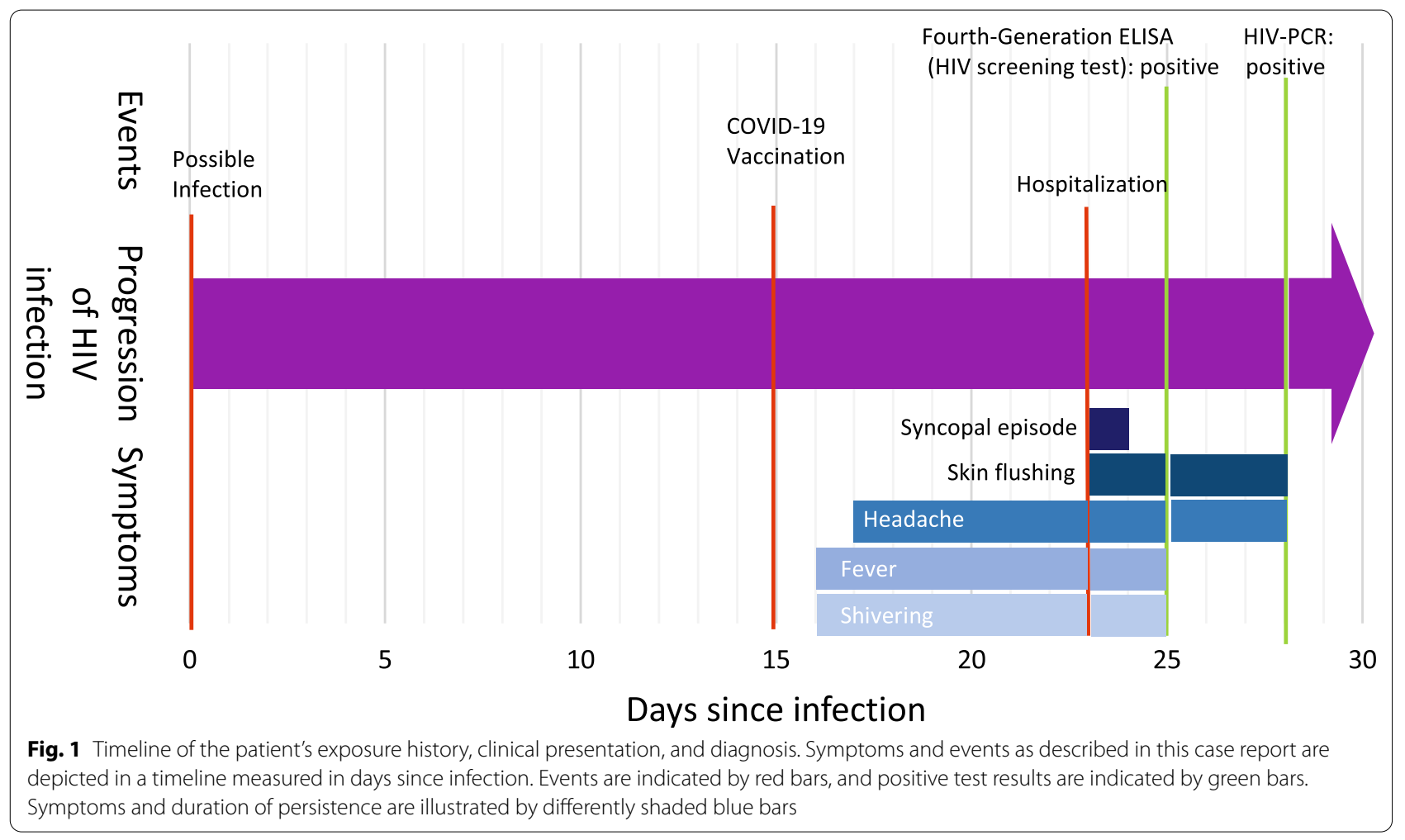


Blood biochemistry showed an elevated C-reactive protein $(\mathrm{CRP})$ level $(2.0 \mathrm{mg} / \mathrm{dL}$; reference: $<0.5 \mathrm{mg} / \mathrm{dL})$ and hematology showed lymphocytopenia $(2.49 \mathrm{G} / \mathrm{L})$, with a CD4 T-cell count of 284 cells $/ \mu \mathrm{L}$ and a CD4/CD8 ratio of 0.2. He was retested for HIV using a screening test (HIV $\mathrm{Ag} / \mathrm{Ab}$ Combo performed on Abbott Architect, Chicago, Illinois, USA) and HIV-immunoblot (recomLine HIV-1 and HIV-2 by Mikrogen, Neuried, Germany). The screening test was reactive but the HIV-specific western blot was negative and no HIV-specific antibodies were detected. Realtime HIV polymerase chain reaction (PCR) testing (Abbott, Chicago, Illinois, USA) revealed a high viral load of 49,817,530 copies/mL, thus confirming the diagnosis as Fiebig stage II acute HIV infection, as shown in Table 1. Coinfection with SARS-CoV-2 was excluded multiple times by SARS-CoV-2 PCR (TaqMan ${ }^{\mathrm{TM}}-\mathrm{PCR}$ performed on Roche cobas $^{\circledR}$ 6800, Basel, Swiss). The patient was discharged without any symptoms and initiated on antiretroviral therapy with bictegravir/emtricitabine/tenofovir alafenamide.

\section{Discussion and conclusion}

This case report illustrates how symptoms of acute HIV infection can be mistaken for side effects of COVID-19 vaccination, especially during the current period of mass COVID-19 vaccination during the ongoing pandemic. Given the similarity of symptoms, including fatigue, fever, erythema, headache, and drowsiness, primary HIV infections can easily be overlooked, and symptoms of acute HIV infection can be falsely attributed to vaccine side effects. During the diagnostic evaluation, detailed history-taking, including inquiring about recent sexual behavior, is key to assessing the risk of HIV infection. Risk factors or indicators include unprotected sexual intercourse, the presence of other sexually transmitted infections, injection drug use, receiving injections with unsterile equipment, accidental needlestick injuries, and unsterile cutting or piercing. Especially in high-risk groups, such as men who have sex with men, sex workers, and injection drug users, patients reporting flu-like symptoms should always be questioned about their recent sexual behavior and drug use history to identify a history of possible HIV exposure and followed up by thorough diagnostic testing for recent HIV infection. Oral ulceration and weight loss have the highest specificity, while fever and rash are the best independent predictors of primary HIV infection, making these symptoms particularly important to note [6].

Although testing for HIV is very reliable in diagnosing infection due to the high sensitivity of HIV screening tests and high specificity of confirmatory testing according to predetermined guidelines, there are still diagnostic gaps in early infection [7]. Such gaps could easily lead to the diagnosis of acute HIV infection being missed, especially if the symptoms occur following vaccination. Though significant progress has been made in diagnostics for early diagnosis, the delay between infection and fourth-generation HIV screening tests becoming reactive is approximately 17-21 days (or 22-24 days with third-generation screening tests) (Table 1). It takes further 14 days until the reactive screening test can be confirmed to enable time for formation of enough HIVspecific antibodies to achieve the predetermined criteria (3/3 antibodies positive against: $\mathrm{p} 24$, gp41, gp120). These diagnostic gaps make it easy to abandon a preliminary diagnosis of primary HIV infection, if the screening test result is not confirmed by the initial confirmatory test.

The possible consequences of misdiagnosis of primary HIV infection are serious. By missing the opportunity for early diagnosis and treatment, infected individuals could experience progression of disease thus leading to a worse outcome. The START trial showed that early initiation of treatment lowers the risk of acquired immunodeficiency syndrome (AIDS) related events by $72 \%$ and of nonAIDS events by $39 \%$ [8]. Early initiation of antiretroviral therapy (ART) also limits the HIV reservoir and allows optimal immune restoration, thus enabling best possible outcome [9].

Furthermore, overlooking the diagnosis in the stage of primary HIV infection misses the opportunity to prevent HIV transmission to others. The concentration of HIV RNA is reached in early stages of infection around the time of seroconversion, making these individuals especially contagious. Brenner et al. [10] estimated that approximately half of the cases of HIV transmission occur in the early stage of infection, making early diagnosis and treatment a powerful tool in preventing the spread of HIV.

In conclusion, this case report highlights the possibility of symptoms and test results in early HIV infection being misinterpreted due to concurrent COVID-19 vaccination and the diagnostic gap in early infections, making it easy to falsely attribute symptoms to vaccine-associated side effects.

\section{Abbreviations}

AIDS: Acquired immunodeficiency syndrome; ART: Antiretroviral therapy; COVID-19: Coronavirus disease; CRP: C-reactive protein; ELISA: Enzyme-linked immunosorbent assay; HIV: Human immunodeficiency virus; MSM: Men who have sex with men; PCR: Polymerase chain reaction.

\section{Acknowledgements}

Not applicable.

\section{Authors' contributions}

All authors contributed to diagnosis and patient care. This article was mainly written by JT and supervised by CDS. All authors read and approved the final manuscript. 


\section{Funding}

Open Access funding enabled and organized by Projekt DEAL. Not applicable.

\section{Availability of data and materials}

All data generated or analyzed during this study are included in this published article.

\section{Declarations}

Ethics approval and consent to participate Not applicable.

\section{Consent for publication}

Written informed consent was obtained from the patient for publication of this case report. A copy of the written consent is available for review by the Editor of this journal.

\section{Competing interests}

Christoph Spinner reports grants, personal fees, and non-financial support from AbbVie; grants, personal fees, and non-financial support from Apeiron; grants, personal fees from B. Braun Melsungen, grants from Cepheid, personal fees from Formycon, grants, personal fees, and non-financial support from Gilead Sciences; grants and personal fees from Eli Lilly; grants, personal fees, and non-financial support from Janssen-Cilag; personal fees from Molecular partners, grants, personal fees, and non-financial support from GSKVViiV Healthcare; grants, personal fees, and non-financial support from MSD, outside the submitted work. Simon Weidlich reports personal fees and non-financial support from Gilead Sciences and Janssen-Cilag. No additional competing interests by any authors of this article.

\section{Author details}

${ }^{1}$ Department of Internal Medicine II, University Hospital Rechts Der Isar, School of Medicine, Technical University of Munich, Ismaninger-Straße 22, 93675 Munich, Germany. ${ }^{2}$ Institute of Virology, School of Medicine, Technical University of Munich, Munich, Germany. ${ }^{3}$ Max Von Pettenkofer Institute, German National Reference Centre for Retroviruses at Ludwig Maximilian University of München, Munich, Germany.

Received: 1 September 2021 Accepted: 11 October 2021 Published online: 26 October 2021

\section{References}

1. Fiebig EW, Wright DJ, Rawal BD, Garrett PE, Schumacher RT, Peddada L, et al. Dynamics of HIV viremia and antibody seroconversion in plasma donors: implications for diagnosis and staging of primary HIV infection. AIDS. 2003;17(13):1871-9.

2. Santangelo J. Acute seroconversion of HIV infection in the ambulatory care setting. Nurse Pract. 2001;26(4):48, 51-4,6.

3. Anand P, Stahel VP. Review the safety of Covid-19 mRNA vaccines: a review. Patient Saf Surg. 2021:15(1):20.

4. Cohen MS, Shaw GM, McMichael AJ, Haynes BF. Acute HIV-1 infection. N Engl J Med. 2011;364(20):1943-54.

5. Facente SN, Grebe E, Pilcher CD, Busch MP, Murphy G, Welte A. Estimated dates of detectable infection (EDDIs) as an improvement upon Fiebig staging for HIV infection dating. Epidemiol Infect. 2020;148: e53.

6. Hecht FM, Busch MP, Rawal B, Webb M, Rosenberg E, Swanson M, et al. Use of laboratory tests and clinical symptoms for identification of primary HIV infection. AIDS. 2002;16(8):1119-29.

7. Beelaert G, Fransen K. Evaluation of a rapid and simple fourth-generation HIV screening assay for qualitative detection of HIV p24 antigen and/or antibodies to HIV-1 and HIV-2. J Virol Methods. 2010;168(1-2):218-22.

8. INSIGHT START Study Group, Lundgren JD, Babiker AG, Gordin F, Emery S, Grund B, et al. Initiation of antiretroviral therapy in early asymptomatic HIV infection. N Engl J Med. 2015;373(9):795-807.

9. Hocqueloux L, Avettand-Fenoel V, Jacquot S, Prazuck T, Legac E, Melard A, et al. Long-term antiretroviral therapy initiated during primary HIV-1 infection is key to achieving both low HIV reservoirs and normal T cell counts. J Antimicrob Chemother. 2013;68(5):1169-78.

10. Brenner BG, Roger M, Routy JP, Moisi D, Ntemgwa M, Matte C, et al. High rates of forward transmission events after acute/early HIV-1 infection. J Infect Dis. 2007;195(7):951-9.

\section{Publisher's Note}

Springer Nature remains neutral with regard to jurisdictional claims in published maps and institutional affiliations.
Ready to submit your research? Choose BMC and benefit from:

- fast, convenient online submission

- thorough peer review by experienced researchers in your field

- rapid publication on acceptance

- support for research data, including large and complex data types

- gold Open Access which fosters wider collaboration and increased citations

- maximum visibility for your research: over 100M website views per year

At BMC, research is always in progress.

Learn more biomedcentral.com/submissions 